\title{
The Effect of Coconut Water Consumption On Labor Advancement in The Phase I Activities in The Mother
}

\author{
Ratih Kusuma Wardhani, Endah Ernawati, Vide Bahtera Dinastiti \\ Pamenang Midwifery Academy, Kediri, Indonesia \\ wardhanipc@gmail.com
}

\begin{abstract}
Prolonged labor can increase abnormalities in the physiology of labor and increase the number of labor with cesarean section. Efforts in overcoming the progress of labor are hampered by caring for the mother in the labor process, including giving freedom to the mother to eat or drink as long as the mother wants to need fulfill her nutrition. This research was Analyze the effect coconut water consumption to advancement labor of active process phase I to intranatal. Design was used quasy experimental with One group pre and post test technique. Data was analyzed with Mann-Whitney. Result showed that there was p-value $0,043<\alpha(0,05)$ so There was a significant influence of the provision of coconut water on the progress of labor in the first stage. There are correlation coconut water on average accelerates the opening by 54 minutes.
\end{abstract}

Keywords: Influence, Coconut Water, progress of labor 


\section{STRADA Jurnal Ilmiah Kesehatan}

DOI: $10.30994 /$ sjik.v8i2.225

ISSN: 2252-3847 (print); 2614-350X (online)

Vol.8 No.2. November 2019. Page.152-157

\section{BACKGROUND}

Childbirth is a series of processes that end with the expenditure of conception results by mothers. The process begins with a true labor contraction, which is characterized by progressive changes in the cervix, and ends with the placental Labour (Varney,2007). Progressive changes in the cervix (thinning and opening) due to his adequate influence (contraction) (Ardhiyanti and Susanti,2016; Kuswanti,2013). In the Primigravida experience the active phase lasts 4-6 hours (Martin, 2011). In addition there is Walsh's statement (2007) that the average Primigravida opening $1 \mathrm{~cm} / \mathrm{h}$. Then the progress of childbirth if hindered can lead to long childbirth, based on data SDKI 2012 the incidence of old Partus reaches 53\% (Martin,2013; Ainny, 2014). Prolonged delivery can increase the abnormalities in the physiology of childbirth and the increase in the number of childbirth with the sexist Sesaria (Walsh, 2007).

Efforts to cope with the progress of labor that has been blocked is required for maternal affection in the process of childbirth, including giving freedom to the mothers eat or drink as long as the mother wants it to fulfill its nutritional needs (JNPK-KR,2008). The fulfillment of nutrients and fluids is an important factor during the labor process to ensure the adequacy of energy and maintain a normal fluid and electrolyte balance in the mother and its plans to prevent dehydration (dehydration may inhibit contraction/irregular and less effective) (Saidah, 2016). Therefore, it is necessary fluids that contain many minerals, some minerals in the bladder by coconut water other than that coconut water also contains very complete nutrients (Lingga, 2012).

Coconut water has chemical and physical properties similar to human plasma, one isotonic that supplies a number of important minerals so that it is able to create body fitness. The ions in coconut water can create a very good balance of blood electrolytes so that the body feels fresh (Lingga, 2012). The content of coconut water contains a number of nutrients, namely $0.2 \%$ protein, fat $0.15 \%$, carbohydrate $7.27 \%$, sugar, vitamins, electrolytes and growth hormone. Maximum sugar content is 3 grams per $100 \mathrm{ml}$ of coconut water. The types of sugar contained are sucrose, glucose, fructose and sorbitol (Saidah, 2016; Djoehana, 2006).

The results of the study of Susiloningtyas, L. (2016) stated that there is influence of coconut water giving to the quality of his childbirth I. Other research from Ainny (2014) suggests that the provision of young coconut water to an intranatal mother reaches $90 \%$ of the mother undergo a physiological (normal) childbirth process. The statement was supported by the research of Saidah, N (2016) that the results of his significant research on the provision of young coconut water is effective in overcoming the long time II on the mother of Intranatal. Therefore, coconut water administration is assessed more efficiently compared with ordinary mineral water, because the young coconut water containing the electrolyte, isotonic, minerals and other vitamins will increase the strength of the mother (Yessy, 2015). Research discussing about coconut water with the progress of Labor active process phase I was not still much.

\section{OBJECTIVE}

This study aimed to examinethe effect coconut water consumption to advancement labor of active process phase I to intranatal in Puhjarak Community Health Center Kediri district. 


\section{STRADA Jurnal Ilmiah Kesehatan}

DOI: $10.30994 /$ sjik.v8i2.225

ISSN: 2252-3847 (print); 2614-350X (online)

Vol.8 No.2. November 2019. Page.152-157

\section{METHODS}

The approach was a quasi-experimental (Quasy Experimental) cross sectional approach. While the research design was used non equivalent control group design. The study was conducted from May to July 2019. The research was conducted in Puhjarak Community Health Center in Kediri Districts, the sampling technique used was purposive sampling. The sample consisted was 20 respondents (control group and treatment group), with inclusion criteria: latent phase, 37-40 weeks gestational age, normal pelvic size, interpretation of fetal weight 2500-4000 grams, single fetus, head presentation; Exclusion criteria: Rohyati praise score $>8$, patient referred, active phase. Coconut water research instruments and partograph sheets. Implementation of Ethics Test in Health Polytechnic Ministry of Health Malang. Study implementation: Respondents in the treatment group in the latent phase were given coconut water (500 $\mathrm{ml}$ volume), assessing the progress of labor in the active phase. Data analysis was used Mann-Whitney test.

\section{RESULTS}

Data Research respondents control group was obtained the average frequency of initial opening of childbirth was $6.5 \mathrm{~cm}$ and the length of the opening during childbirth was 3.10

hours. While the treatment group data obtained the average frequency of early labor opening is $5.8 \mathrm{~cm}$ and the length of opening during childbirth was 2.20 hours. The difference in length of time opening in the control group and the treatment was $=0.9$ hours. Mean giving average coconut water speeds up the opening by 54 minutes.

Data showed only $5 \%$ (1 respondent) of all respondents whose opening duration was 1 hour, whereas in the control group the duration of opening was 2 hours by $15 \%$ ( 3 respondents) and in the treatment group it was higher at $35 \%$ ( 7 respondents). At the opening time of 3 hours, the number of control groups was greater than the treatment group at 15\% (3 respondents) while the treatment group was 5\% (1 respondent). And at the opening time 4 hours was greater in the control group by $20 \%$ (4 respondents), while the treatment group was 5\% (1 respondent). Data showed 45\% (9 respondents) of the treatment group had the fast delivery category while the control group was $25 \%$ ( 5 respondents). For the normal delivery time category, the percentage in the control group was higher at $10 \%$ ( 2 respondents) while the treatment group was 5\% ( 1 respondent). While the category of slow labor obtained results only in the control group was equal to $15 \%$ (3 respondents) of the total delivery.

The test results could from the existing significance price (Asymp.Sig) which was 0.046 where the price was compared with $\alpha=0.05$, so that the significance $(\mathrm{p}<0.05)$ was Ho rejected, which means the data was not normally distributed, so the assumption not met, then conduct data analysis using the Mann-Whitney test

The hypothesis of this study was that Ho: there was'nt difference in the duration of the treatment group opening with the control group, whereas $\mathrm{H} 1$ : there was a difference in the duration of the treatment group opening with the control group. Where sig $(p)=0.043, \alpha=$ $5 \%=0.05, \mathrm{p}$ value calculated $<\alpha$ then Ho was rejected, it means there was a difference in the duration of the treatment group opening with the control group, the difference was due to the influence of the treatment, so it can be concluded there was an influence of water administration coconut on the progress of labor in the first stage. 


\section{STRADA Jurnal Ilmiah Kesehatan}

DOI: $10.30994 /$ sjik.v8i2.225

ISSN: 2252-3847 (print); 2614-350X (online)

Vol.8 No.2. November 2019. Page.152-157

\section{DISCUSSION}

The fluid and nutritional needs during labor has not been studied. The metabolic process is generally tailored to the needs of the body, so energy requirements increase during pregnancy and childbirth. During the labor process will undergo a change of ketone levels which is associated with the presence of famine or the maternal stress due to the energy that has been used, but the incident is considered a physiological response with a slight clinical significance ( Low ketone levels often occur during labor) (Singata, Tranmer, Gyte, 2013). When the process of childbirth consuming food and drink allows the mother to feel normal and healthy, make her energy remains active and minimize the complications that are thought out by dehydration and maternal fatigue. This is in line with Simkin's research (1986) that the feeling of fear, emotional and stress of a mother during childbirth there is a relationship of obstetric intervention about $57 \%$ because during the process of labor fluid intake per oral Dibatasai about 27\% ( Davie,2012; Wahyuni,2017).

According to T. Stork (2016) The use of (consumption) of oral fluid from clear liquids (water, fruit juices without slurries, clear tea, coconut water) is allowed against women during childbirth. In addition to his stomach is never completely empty and increased gastric acidity, which can lead to aspiration and as a treatment of dehydration (fatigue) (Wahyuni,2017; T. Stork,2016; Ainny,2014).

Providing fluids and nutrients during labor will provide more energy and prevent dehydration which results in slowing contractions or making irregular contractions. Maternity women need $\pm 50-100 \mathrm{kCal}$ of energy every hour which must be fulfilled during delivery so as to prevent muscle fatigue and hunger. If glucose reserves are not available fat reserves will be used and will result in ketosis in the end ketonuria, which causes reduced myometrial work (T.Stork, 2016).

Research that discusses about coconut water with the progress of labor in the first phase of active phase in intranatal is still not much. So the provision of coconut water is considered more efficient than ordinary mineral water, because young coconut water can maintain and increase glucose levels needed as a substitute for body fluids (Syafriani, 2012).

Based on the results of the Mann-Whitney test, the results showed an effect of coconut water consumption on the duration of the first stage of labor. Based on the statistical test analysis, it was found that the significance value of $p$ value was calculated $(0.043)<p$ value of table 0.05. From these results it can be concluded that Ho is rejected means there was a difference in the duration of the opening of the treatment group with the control group, the difference is due to the influence of the treatment, so it can be concluded there is an effect of giving coconut water to the progress of labor at the first stage. 54 minutes. This is in accordance with the theory of Almatsier (2004) in Khotimah's research (2013) that the need for electrolytes in the body is around $155 \mathrm{meq} / 1$ with the mother consuming $500 \mathrm{ml}$ of coconut water during the latent phase minimizing dehydration because coconut water contains the required cations and anions by the body as an electrolyte liquid (Almatsier, 2004; Khotimah, 2013).

In line with the research of Syafriana, et al (2012) about the effect of palm-soon water and istonic drinks on blood glucose levels, there was a result that the group of palm-water-palmwater groups had significantly higher differences compared to the isotonic drinks group. The level of sugar (glucose reserves) in a stable blood can increase the work of myometrium (contraction) (Syafriani, 2012). 


\section{STRADA Jurnal Ilmiah Kesehatan}

DOI: $10.30994 /$ sjik.v8i2.225

ISSN: 2252-3847 (print); 2614-350X (online)

Vol.8 No.2. November 2019. Page.152-157

Research Kumarawati, et al (2010) about the effect of pocari sweet administration on the quality of labor delivery using primiparous maternal respondents, there is a significant difference in the quality of pesticide with a $0.01 \mathrm{p}$ value in the intervention group showing the average frequency of his 4 times in 10 minutes with the intensity good for 39.58 seconds (Kumarawati, 2010).

The results of this study are not in line with Khotimah's research (2013) that the administration of pocari sweet to the duration of the first stage of labor did not have a significant effect with a $p$ value of 0.150 . This is because using respondents in multiparous mothers who have differences in length of labor, cervical opening speed of $1 \mathrm{~cm}$ per half hour (Khotimah, 2013).

Proper handling of labor will lead to an increase in the well-being of the fetus and mother during the delivery process, the mother will feel comfortable and reduce the adverse effects / complications on the mother and fetus.

\section{CONCLUSION}

The consumption of coconut water can affect the progress of labor. The consumption of coconut water can be used as an alternative to accelerate the process of labor during 1 phase active in Indonesia. Advice should be advanced research on consumption of coconut water on progress of labor process phase II.

\section{ACKNOWLEDGE}

The authors wish to thanks Direktorat Riset dan Pengabdian Masyarakat (DRPM) Kemenristekdikti 2019 with research contract No. 147/SP2H/LT/MONO/L7/2019. The authors also wish to thanks PMB Wilayah Kerja Puskesmas Puhjarak Kabupaten Kediri.

\section{REFERENCES}

Ainny, D.N. 2014. KTI Efektivitas Pemberian Air Kelapa Muda Terhadap Lama Persalinan Kala II Pada Ibu Intranatal Di BPM Ny. "M” Pungging Mojokerto. Mojokerto

Almatsier, Sunita. 2004. Prinsip Dasar Ilmu Gizi. Jakarta: Gramedia Pustaka Utama

Ardhiyanti, Y dan S. Susanti. 2016. Faktor yang Berhubungan dengan Kejadian Persalinan Lama di RSUD Arifin Achmad Pekanbaru. Jurnak Kesehatan Komunitas, Vol.3, No.2, Mei 2016

Davie, Mary-Rose. 2012. Evidance Based Guidelines for Midwifery-Led Care in Labour. Nutrition in Labour. Evidance Based Guidelines for Midwifery-Led Care in Labour

(C) The Royal College of Midwives 2012

Djoehana, S. 2006. Bertahan Kelapa. Yogyakarta: Kanisius

Erma Kumarawati, Sunarto, Nurlailis Saadah. 2010. Pengaruh Pemberian Pocari Sweet Terhadap Kualitas HisPersalinan. Jurnal Penelitian Kesehatan Suara Forikes, Volume 1 No.1, Januari 2010.

JNPK-KR.2008. Buku Acuan Pelatihan Klinik Asuhan Persalinan Normal Revisi 5. Edisi 2008. Departemen Kesehatan Republik Indonesia

Khotimah, N. 2013. Pengaruh Pemberian Pocari Sweet Terhadap Lama persalinan Kala I Di BPM Endang Purwaningsih Bantul. Karya Tulis Ilmiah Prodi D III Kebidanan Stikes A.Yani Yogyakarta.

Kuswanti, Ina. 2013. Askeb II Persalinan. Yogyakarta: Pustaka Pelajar

Lingga, Lanny. 2012. Terapi Air Kelapa. Jakarta: PT. Elex Media Komputindo 


\section{STRADA Jurnal Ilmiah Kesehatan}

DOI: $10.30994 /$ sjik.v8i2.225

ISSN: 2252-3847 (print); 2614-350X (online)

Martin, Reeder. 2011. Keperawatan Maternal Kesehatan Wanita, Bayi dan Keluarga eds.18 vol. 1. Jakarta: EGC

Saidah, N. 2016. Efektifitas Pemberian Air Kelapa Muda Terhadap Lama Kala II Persalinan Pada Ibu Intranatal Di BPM Ny. "N". Health Sciences Journal, Vol.2, No. 1, April 2016

Singata, M; J. Tranmer; G.M. Gyte. 2013. Restricing oral fluid and food intake during labour. Europe PMC (8). http//doi.org/10.1002/14651858.CD003930.pub3

Surtiningsih. 2017. Faktor-faktor yang Mempengaruhi Lama Waktu Persalinan Di Puskesmas Klampok 1 Kabupaten Kediri. Jurnal Ilmiah Kebidanan, Vol.8 No.2 Edisi Desember 2017, hlm. 101-115

Susiloningtyas, L. 2016. Pengaruh Pemberian Air Kelapa Terhadap Kualitas HIS Persalinan Kala I. Jurnal ADRI

Syafriani, R., dkk. 2012. Pengaruh Air Kelapa Genjah Salak (Cocos Nucifera L) dan Minuman Isotonik Terhadap Kadar Glukosa Darah. Jurnal Medika Planta: Vol 1. No.5, April 2012

T.Stork. 2016. Malta Midwives_Nutritiont in Labour. Malta Midwives Association. Issues 8 July 2016. Malta midwife's journal. www.midwivesassoc.wix.com $/ \mathrm{mma1974}$

Varney, Halen. 2007. Buku Ajar Asuhan Kebidanan vol 2 eds 4. Jakarta: EGC

Wahyuni, Islah.,dkk. 2017. Managemen Kelelahan Saat Persalinan Menggunakan Jus Semangka. Jurnal Ipteks Terapan. Research of Applied Science and Education V12.i 1 (19-31). http://doi.org//10.22216/jit.2018.v12i1.2358

Walsh, L.V. 2007. Buku Ajar Asuhan Kebidanan Komunitas. Jakarta: EGC; 235-355

Yessy, A. 2015. 5 Manfaat Air Kelapa Untuk Ibu Hamil dan Bersalin. http://bidanku.com. Diakses pada tanggal 19 Juni 2018 